\title{
Psychosocial Stress among Bankers Due To Long Working Hours: Case Study of University of Cape Coast Banks.
}

\author{
Rev. Dr. Kwasi Otopa Antiri \\ Department of Guidance and Counselling, University of Cape Coast, Cape Coast. Ghana. \\ And \\ Dr. Bakari Yusuf Dramanu \\ Department of Education and Psychology, University of Cape Coast, Cape Coast. Ghana.
}

\begin{abstract}
The study aimed at investigating the impact of psychosocial stress among bankers in the University of Cape Coast in the Central Region of Ghana. The study focused specifically on the following: examine the psychosocial stress on bankers due to long working hours, find out the strategies that bankers could adopt to reduce stress associated with long working hours and lastly assess the impact of psychosocial stress on the health of bankers. The convenience sampling technique was used to select 76 participants for the study. The results of the study indicated that on the psychosocial stress associated with long working hours among bankers, bankers generally reported that they were aware of the psychosocial stress based on the statement outlined on the questionnaire. Health-wise, to a great extent that psychosocial stress associated with long working hours do not affect the health of bankers in the University of Cape Coast. Management commitment to employee-related issues such as paying attention to workload conflict and the introduction of proper stress management training programmes were perceived as significant steps which if embraced, were identified as major contributory factors that could contribute to the alleviation of psychosocial stress among staff.
\end{abstract}

Keywords: Psychosocial stress, Bankers, Cognitive Appraisal and Social status.

\section{Background to the study}

Many organizations are prone to long working hours. While some employees, due to higher salaries, resort to working overtime, others spend much time at work due to the nature of their work, with or without wages. Long working hours are common worldwide; for example, in the European Union member states, $12 \%$ - 17\% of employees worked overtime in 2001 (Virtanen, et. al, 2009).

Anecdotal evidence shows that like any average Ghanaian employee, bankers' usual working hours are from 8:00 AM to 5:00 PM with an hour break. Bankers, however, do not close from work completely when it is 5:00 PM. The banks on the campus of University of Cape Coast in the Central Region of Ghana which are Agricultural Development Bank, Unibank Limited, and Zenith Bank, close their banking halls at 5.00PM until they have finished with their transactions for the day, irrespective the number or the workload.

Even after serving all the customers who may be at the banking halls after closing time, bankers will still be at the banking halls accounting for the day's transactions. Hence they sometimes end up leaving for their homes at 8:00PM.

Having long working hours, even at the desk, can have serious repercussions for one's physical and mental health. For example; research has shown that, those who spend four or more hours sitting per day have a 125 percent increase in heart disease risk, and a 50 percent increased risk of death from any cause (Berkowitz \& Clark, 2014). According to researchers at University College in London, stressful work conditions, including long work hours, can double your risk of depression. A Gallup poll of nearly 240,000 full-time workers found that 10.8 percent of U.S. full-time workers have received a depression diagnosis (Bixby, 2014). Notwithstanding, the possible awareness of the risk of working for longer hours, bankers on the campus of University of Cape Coast still bear the risk of causing harm to their health because they work at a community which is highly populated with over 20,000 students. Bankers barely get time to rest aside the normal working days. The University of Cape Coast campus banks do operate on Saturdays apart from the week days' service.

Stress arises when individuals perceive a discrepancy between the physical or psychological demands of a situation and the resource of his or her biological, psychological and social systems (Sarafino, 2012). Stress comes in many forms but this study is geared towards the psychosocial form of stress. Psychosocial stress is the result of a cognitive appraisal of what is at stake and what can be done about it. Psychosocial stress results when we look at a perceived threat in our lives (real or even imagined), and discern that it may require resources we don't have. Examples of psychosocial stress include threats to our social status, social esteem, respect, and/or acceptance within a group; threat to our self-worth; of a threat that we feel we have no control over (Scott, 2014). 
This study seeks to find out the psychosocial stress among bankers due to long working hours and interventions that can be applied by Management and employees to manage stress effectively at the banks on the campus of University of Cape Coast.

\section{Statement of the Problem}

The current busy environment in which some workers conduct their work requires that organizations examine their practices. Working at the bank is an inherently stressful profession with heavy workloads, difficult customers and conflicting demands. The physical and psychological demands of bankers make them vulnerable to working longer hours. Anecdotally, the effects of long working hours are evidenced as increased errors, high medical bills, lateness to work and increased sick leaves. Despite the extremely negative effects of long working hours on the human body and psychosocial stress, many banks who operate at the University of Cape Coast campus with no exceptions, have not put in any concrete measures to address these long working hours' related conditions that negatively affect bankers. Furthermore, there has not been a conscious establishment of a linkage between long working hours and its influence on bankers in the University of Cape Coast. It is in the light of these problems that this research seeks to bring to the fore, psychosocial stress among the bankers.

\section{Research Questions}

The study was guided by the following research questions and hypothesis:

1. What are the psychosocial stress among bankers as a result of long working hours?

2. What are the strategies that could be adopted by bankers to reduce stress associated long working hours among bankers in University of Cape Coast?

\section{Hypothesis}

Ho: There is no statistical significant relationship between psychosocial stress and health of bankers.

$\mathrm{H}_{1}$ There is statistical significant relationship between psychosocial stress and health of bankers.

Adequate rest is important to healthy functioning of organizations as it seeks to increase employee performance since one can clearly focus on tasks, better memory, improved immune system and better blood pressure. In Ghana, stress is not being given the attention it deserves. It is in the light of this that this study is deemed important, as it will:

1. Create awareness among managers on the need to provide the needed platform to help staff deal with their stresses.

2. The study has the potential to stimulate, among scholars and students, an interest in the study of long working hours among workers in Ghana.

\section{Literature Review}

This chapter of the study looks at relevant literature on the influence of long working hours or psychosocial stress among bankers. Literature review has been organized according to theoretical framework and empirical framework. Issues considered in this section would include long working hours and psychosocial stress and health. The theoretical framework addressed theories that are applicable to the study while the empirical frame work concerned what other researchers have found with regard to long working hours and stress.

\section{Theoretical Framework}

Theories help us to understand underlying process and on that basis, choose an effective course of action. According to Stoner and Freeman (1992), a theory is a coherent group of assumption put forth to explain the relationship between two or more observable facts. Valid theories enable us to predict what will happen under certain situations. It is a truism that no matter the degree of the grasp of a principle, the history and theories of any field help us to apply them to actual cases. In reviewing literature in the study of psychosocial stress among bankers due to long working hours, theories that served as anchor to the study include; stimulusbased, response-base, interactional, person-environment fit, role overload and role theory.

\section{Theoretical Approaches to Stress}

There are a wide variety of various definitions and theories pertaining to the dynamic construct of stress. In an attempt to organize all of these theories Ghadially and Kumar (1987) suggested that there were at least three distinct orientations, which were (a) stimulus-based, (b) response-based and (c) interactional. Subsequent literature supports the idea that there are three different theoretical approaches to the concept of stress (Richard \& Krieshok, 1989; Ryan, 1996; Trivette, 1993). 
Stimulus-based: Kahn (1986) defines stimulus-based stress as 'external forces or conditions that are hypothesized or demonstrated to hve negative (painful, damaging, incapacitating) effects on the organisms of interest' (p. 42) Stimulus-based stress theorists believe that the factors in the environment exert an influence on an individual (Derogatis \& Coons, 1993; Lazarus \& Folkman, 1986; Meichenbaum, 1986). Essentially this model proposes that external stressors in the environment result in a stress reaction or strain (Cox, 1979). In addition, Derogatis \& Coons (1993) identified different categories of stimulus stressors, in terms of their ability to induce stress, such as: (a) acute, time limited stressors; (b) chronic intermittent stressors; (c) stressor sequences ; and (d) chronic stressors.

\section{Response -base}

Stress is seen as a psychological or physiological reaction to a stressor or stressors (Richard \& Krieshok, 1989). This was also the viewpoint that Selye and others utilized as the foundation for their work as stress researchers (Chesney \& Rosenman, 1983; Selye, 1974; 1976; 1983 1993). Although in one of his later publications Selye admitted, "I should have called my phenomenon the ' strain reaction' and that which causes it 'stress,' which would parallel the use of these terms in physics " ( Selye, 1976, p. 50 ). If this had been the case, than current theorists might have considered Selye's model interactional or transactional versus responsebased.

\section{Interactional}

The interactional approach to stress incorporates both stimulus-based and response -based approach (Cox 1979; Richard \& Krieshok, 1989). This theory has also been referred to as the stimulus-response interaction (Greenberg, 1999) and is sometimes used to refer to the transactional approach (Derogatis \& Coons, 1993). The interactional approach stipulates that situational variables interact with personal variables from which strain results (Ryan, 1996).

Current research supports the theoretical construct set forth by the interactional approach. Fogarty el al. (1999) conducted four separate studies which analysed occupational stress, strain, and coping through path analysis. Fogarty el al. concluded that, in all four studies that stress and coping variables were able to significantly predict the amount of variance in strain. Decker and Borgen (1993) also advocate for an interactional approach for researchers interested in studying variables related to occupational stress, stain and coping because they feel it "fully examines the individual's unique psychological experience of work" (p. 477).

Cox and McKay took the interactional approach to stress one step further and have proposed that there is another fact to this approach (Cox, 1979). This theory has been referred to as transactional (Greenberg, 1999). The transactional approach incorporates the stimulus, response, cognitive appraisal if the stressor, coping style of the individual, psychological defences, and social milieu into account (Folkman \& Lazarus, 1988a, 1988b). A transactional approach suggests that "not only does the individual mediate the impact of environmental stimulus upon responses, but, in addition, the perceptual, cognitive, and physiological characteristics of the individual affect and become a significant component of the environment" (Derogatis \& Coons, 1993).

\section{Role theory}

In order to fulfil expected service outcomes "over the last decade human service agencies in most western economies have undergone major organizational restructuring and redefinitions of professional roles" (Biggs, Flett, Voges \& Alpass, 1995). One of the basic premises of the role theory is that, various occupational roles that individuals engage in may be stressful regardless of their actual occupation, suggesting that stress found in various work roles may be stressful for all workers. Osipow and Spokane (1987) described six work roles that they felt were stressful regardless of an individual's actual vocational choice. These six roles were also utilized in the revised version of the OSI and include: (a) role ambiguity, (b) role insufficiency, (c) role overload, (d) role boundary, (e) responsibility, and (f) environment ( Osipow \& Spokane, 1987; Osipow, 1998).

\section{Person -Environment fit}

A review of the literature suggests that researchers have attempted to find an explanation regarding the potential relationship that exists between stress, an individual, and the environment. It has been theorised that if there is not an accurate fit between the person and the environment, strain will occur (French, Caplan, \& Harrison, 1982). More specifically, a person environment (P-E) fit suggests that individuals fit certain occupations based on the interaction of a multitude of variables. Theoretically, P-E fit "predicts that the magnitude of strain experienced by an individual is proportional to the degree of misfit between the individual and their occupation" (Pithers \&Soden, 1999, p.58). French et al. indicated that, individual vary in their needs and abilities just as jobs vary in their incentives and demands. Lazarus and Folkman (1986) believe that the 
interaction between how an individual affects the environment and vice versa is a complex bi-directional process that is a result of a variety of factors and not any single variable.

The P-E fit theory has attracted researchers who believe there is some efficacy in its relationship to stress (Pithers \& Soden, 1999; Sutherland, Fogarty \& Pithers, 1995). This theory was lent by some empirical evidence by Sutherland et al. Their research supported the idea that stress and strain is "inversely related to measures of P-E fit" (Sutherland et al., 1995, p. 306).

\section{Role Overload}

Role Overload (RO) measures the extent to which job demands exceed resources (personal and workplace) and the extent to which the individual is able to accomplish workloads (Osipow, 1998). Role overload can result in an employee experiencing anger and frustration toward persons believed responsible for the overload in work (Marini, Todd \& Slate, 1995).

Decker and Borgen (1993) found that Role Overloads for University of Califonia workers was modestly correlated with stress. Trivette (1993) found that Role Overload scores for tertiary education worker were in the average range for both genders. However, Trivette found that lecturers who worked at two or more schools had higher stress level. In addition working at two or more schools settings was significantly correlated with higher Role Overload scores in comparison to one school.

\section{Empirical Studies}

\section{Effect psychosocial stress has on cardiovascular disease}

Your cardiovascular system, the network that connects your heart and blood vessels, is your highway of life. Unfortunately, there are accidents along this highway in the form of cardiovascular disease (CVD, or heart and artery disease). CVD is the leading cause of death in the United States, claiming about one million lives annually and accounting for above four in ten deaths, most often as the result of heart attacks or strokes (Hlu \& Willett, 2002; Nabel, 2003).

Coronary heart disease (CHD) is the major form of cardiovascular disease, accounting for above 700,000 deaths annually, mostly from heart attacks. CVD is the leading cause of death for both men and women, claiming even more women's lives than breast cancer. In coronary heart disease, the flow of blood to the heart is insufficient to meet the heart's needs. The underlying disease process in CHD is called arteriosclerosis, or hardening of the arteries, a condition in which artery walls become thicker, harder, and less elastic, which makes it more difficult for blood to flow freely. The major underlying cause of arteriosclerosis is atherosclerosis, a process involving the build-ups of fatty deposits along artery walls that leads to the formation of artery-clogging plaque. If a blood clot should form in an artery narrowed by plaque, it may nearly or completely block that flow of blood to the heart.

The result is a heart attack (also called a Stress, Psychological Factors, and Health myocardial infarction), a life-threatening event in which heart tissue dies due to a lack of oxygen-rich blood. When a blood clot blocks the supply of blood in an artery serving the brain, a stroke can occur, leading to death of brain tissue that can result in loss of function controlled by that part of the brain, coma, or even death. The good news is that CHD is largely preventable (Nabel, 2003). How? By reducing the risk factors that, we can control. There are some risk factors that we cannot control, such as, age and family history. But a number of risk factors can be controlled through medical treatment or lifestyle changes factors such as high blood cholesterol, hypertension (high blood pressure), smoking, overeating, heavy drinking, consuming a high-fat diet, and leading a sedentary lifestyle (Mendelsohn \& Karas, 2005).

Unfortunately, many of these factors remain uncontrolled. For example, only about one in four adults with hypertension take medications to control blood pressure (Chobanian 2001; Hyman \& Willet, W. C., 2002). Adopting healthier behaviours can have beneficial effects on the heart. For example, evidence shows that even seasoned couch potatoes can reduce their risk of cardiovascular disease by becoming more physically active (Blumenthal, Emery \& Madden, 2005; Börjesson \& Dahöf, 2005). Frequent emotional distress in the form of anger, anxiety, and depression can have damaging effects on the cardiovascular system (Frasure-Smith \& Lespérance, 2005; Geipert, 2007; Orth-Gomér et al., 2000).

Researchers highlight the toxic effects of chronic anger on the heart. Occasional feelings of anger may not damage the heart in healthy people, but chronic anger; the type you see in people who seem angry all of the time is linked to increased risk if CHD (Kiecolt-Glaser, McGuire, Robles, \& Glaser, 2002; Pressman \& Cohen, 2005; Rutledge \& Hogan, 2002; Steptoe, Wardle, \& Marmot, 2005). Anger is closely associated with hostility; a personality trait characterized by quickness to anger and by tendencies to blame others and to perceive the world in negative terms. Hostility is a component of the type 'A' behaviour pattern (TABP), a style of behaviour that characterizes people who are hard driving, ambitious, impatient, and highly competitive. Although earlier research had linked the Type 'A' pattern to a higher risk of CHD, more recent research casts doubts, on the relationship between this personality pattern and coronary risk (Geipert, 2007). However, according to Geipert, we have more consistent evidence linking the trait of hostility, a component of the Type 
' $A$ ' pattern, to increased risks of heart disease and other negative health outcomes. Hostile people tend to have short fuses and are prone to get angry, easily.

How might anger and other negative emotions contribute to heart disease? Although we cannot be sure, investigators suspect that the stress hormones epinephrine and norepinephrine play significant roles (Januzzi, Stern, Pasternak, \& DeSanctis, 2000). Anxiety and anger trigger the release of these stress hormones by the adrenal glands. These hormones increase heart rate, breathing rate, and blood pressure, which result in pumping more oxygen rich blood to the muscles to enable them to prepare for defensive action, to either fight or flee, in the face of a threatening stressor. In people who frequently experience strong negative emotions such as anger or anxiety, the body may repeatedly pump out these stress hormones, eventually damaging the heart and blood vessels.

Evidence indicates that episodes of acute anger can actually trigger heart attacks and sudden cardiac death in some people with established heart disease (Clay, 2001). We have also learned that people who are higher in hostility tend to have more cardiovascular risk factors, such as obesity and smoking, than do less hostile people (Bunde \& Suls, 2006). Anxiety and anger may also compromise the cardiovascular system by increasing blood levels of cholesterol, the fatty substance that clogs arteries and increases the risk of heart attacks (Suinn, 2001). Healy and Mckay, (2000) in their research work indicated that there are several ways of managing psychosocial stress. Seeking assistance from a colleague when one is in need of something, taking a walk, exercising, sharing one's problem with others etc. these things would aid an individual to have a alleviate stress.

\section{Conceptual Perspective}

\section{The concept of psychosocial stress}

Modern life is full of frustrations, deadlines, and demands. For many people stress is so common place that it has become a way of life. Stress is not always bad though. Stress within one's comfort zone can help one to perform under pressure, motivates, even keep one safe when danger looms. But when stress becomes overwhelming, it can cause damage to the health, mood, relationship, and quality of life of an individual. Stress is a general term applied to various psychological (mental) and physiological (bodily) pressures experienced or felt by people throughout their lives.

\section{What is stress?}

Stress is defined as a state of psychological and physiological imbalance resulting from the disparity between situational demand and the individual's ability and motivation to meet those needs. Stress is the body's way of responding to any kind of demand or threat. When threatened, the nervous system responds by releasing a flood of stress hormones, including adrenaline and cortisol, which rouses the body for emergency action. The heart pounds faster, muscles tighten, blood pressure rises, breath quickens, and senses become sharper. These physical changes increase strength and stamina, speed reaction time, and enhance focus.

Stress can also help an individual rise to meet challenges. Stress is what keeps one on one's toes during a presentation at work, sharpens one's concentration when one is attempting the game-winning free throw, or drives one to study for an exam when instead of watching TV. But beyond the comfort zone, stress stops being helpful and can start causing major damage to the mind and body. Hence, stress is good when the situation offers an opportunity to a person to gain something. It acts as a motivator for peak performance. Stress is negative when a person faces social, physical, organizational and emotional problems.

When working properly, stress helps in staying focused, energetic, and alert. In emergency situations, stress can save a life, giving an extra strength to defend oneself. This is known as a "fight to flight" stress response and is your body's way of protecting you.

\section{Causes of stress}

The situations and pressures that cause stress are known as stressors. Stressors can either be negative, (such as, an exhausting work schedule or a rocky relationship). However, anything that puts high demands or forces an individual to adjust can be stressful. This includes positive events such as getting married, buying a house, going to college, or receiving a promotion. Stress is caused by external factors such as (a) work or school (b) relationship difficulties, (c) financial problems, (d) being too busy and (e) children and family; or internal factors such as (a) chronic worry, (b) pessimism, (c) negative self-talk, and (d) unrealistic expectations/perfectionism.

\section{Major causes of stress at work or in organization}

Career concern: If an employee feels that he is very much behind in the corporate ladder, then the employee may experience stress. If the employee seems that there are no opportunities for self-growth, the employee may experience stress. Hence, unfulfilled career expectations are the significant source of stress. 
Role ambiguity: It occurs when the person does not know what the person is supposed to do, on the job. The individual's tasks and responsibilities are not clear. The employee is not sure what he or she is expected to do. It creates confusion in the minds of the worker and results in stress.

Rotating work shifts: Stress may occur in those individuals who work on different work shifts. Employees may be expected to work on day shift for some days and then on the night shift. That may create problems in adjusting to the shift timings, and it can affect not only personal life but also family life of the employee.

Role conflict: it takes place when people have different expectations from the person performing a particular role. It can also occur if the job is not as per expectation, or when a job demands a certain type of behviour that is against the person's moral values.

Occupational demands: Some jobs are more demanding than others. Jobs that involve risk and danger are more stressful. Research findings, indicate, job that causes stress needs constant monitoring of equipment and devices, unpleasant physical conditions, making decisions, etc.

Lack of participation in decision-making: Many experienced employees feel that management should consult them on matters affecting their jobs. In reality, the superiors hardly ask the concerned employees before taking a decision. That develops a feeling of being neglected, which may lead to stress.

Work overload: Excessive workload leads to stress as it puts a person under tremendous pressures. Work overload may take two different forms:

1. Qualitative work overload implies performing a job that is complicated of beyond the employee's capacity.

2. Quantitative work overload is a result of many activities performed in a prescribed time.

Poor working conditions: Employees may be subject to poor working conditions. It would include bad lighting and ventilation, unhygienic sanitation facilities, excessive noise, and dust, presence of toxic gasses and fumes, inadequate safety measures, etc. All these unpleasant conditions create physiological and psychological imbalance in humans thereby causing stress.

Lack of group cohesiveness: Every group is characterized by its cohesiveness, although they differ widely in its degree. Individuals experience stress when there is no unit among work group members. There are mistrust, jealousy, frequent quarrels, etc., in groups and this lead to stress to employees.

Interpersonal and intergroup conflict: These conflicts take place due to differences in perceptions, attitudes, values and beliefs between two or more individuals and groups. Such conflicts can be a source of stress for group members.

Organizational Changes: When changes occur, people have to adapt to those changes, and this may cause stress. Stress is higher when changes are significant or unusual like transfer of adoption of new technology.

Lack of social support: When individuals believe that they have the friendship and support of others at work, their ability to cope with the effects of stress increases. If this kind of social support is not available, then an employee experiences more stress.

\section{Signs and symptoms of stress overload}

The more signs and symptoms one experience, the closer the person draws to stress overload. The symptoms categorized into (a) Cognitive symptoms (memory problems, inability to concentrate, poor judgment, constant worrying anxious or racing thoughts), (b) Emotional symptoms (moodiness, depression, agitation, short temper, sense of loneliness and isolation), (c) Physical symptoms (aches and pains, diarrhoea or constipation, chest pain, frequent colds, nausea) and (d) Behavioural symptoms (eating more or less, sleeping too much or too little, isolation, procrastinating or neglecting responsibilities).

\section{Effects of stress overload}

Frequent experience of the fight or flight stress response in life can raise blood pressure, suppress the immune system, increase the risk of heart attack and stroke, speed up the aging process and make one vulnerable to a host of mental and emotional problems. Many health problems that are caused or exacerbated by stress include (a) Pain of any kind, (b) Heart disease (c) Sleep problems, (d) Depression, and (e) Auto immune diseases.

\section{Methodology}

This chapter presents the methodology used to carry out the study. It discusses the research design, population, sample and sampling procedure, research instruments, procedure for data collection and data analysis. Research design is a plan that promotes systematic management of data collection Cooper and Schindler (2003). A research design, according to Orodho (2003) is the scheme, outline or plan that is used to generate answers to research questions. This study adopted the cross-sectional survey method as its research strategy. As noted by Yin (1994), survey is a systematic method for gathering information from a sample of individuals for the purpose of describing the attributes of the large population of which the individuals are members. The cross-section was chosen because it studies the research problem at a point on time and not 
within a longer time frame (longitudinal). This method is considered useful because the problem of study cannot be directly observed. Thus, the psychosocial stress among bankers due to long working hours cannot be directly observed.

The target population for the study consisted of 97 bankers in the University of Cape Coast; 30 staff members of Zenith Bank, 22 of Ghana Commercial Bank, 20 of Unibank Ghana Limited, 7 staff of Agricultural Development Bank, 10 of Fidelity Bank and 8 of Prudential Bank Limited. According to the table of determining the sample size of a known population, a sample size of 76 is needed for a population of 97 (Krejcie $\&$ Morgan, 1970). To ensure good response and return rates of questionnaires, convenient sampling technique was used. Convenient sampling technique allows respondents to voluntarily participate in the study thereby yielding accuracy in the information provided by respondents. The choice of sampling technique became necessary considering the reluctance that people show towards the filling of questionnaires and the limited time to complete the study. All the banks in the University of Cape Coast were visited to call on workers to take part in the study. A close-ended questionnaire with 30 items and 3 sections was used to gather data. The sections of the questionnaire consisted of: Demographic Data, Long Working Hours and Psychosocial Stress, Strategies to Reduce Long Working Hours and Stress and Health for section A, B, C, and D respectively. The questionnaire however, is not without weaknesses. It is quite easy for respondents to provide inaccurate responses.

\section{Results And Discussion}

The study was designed to investigate the impact of psychosocial stress among bankers in University of Cape Coast in the Central Region of Ghana. In research question one, which sought to find out the psychosocial stress among bankers as a result of long working hours. The study aimed in investigating the impact of psychosocial stress among bankers in the University of Cape Coast in the Central Region of Ghana. The study focused specifically on the following: examine the psychosocial stress on bankers due to long working hours to find out the strategies that bankers could adopt to reduce stress associated with long working hours and lastly assess the impact of psychosocial stress on the health of bankers. This chapter presents the results of the analyses and discussion of the findings of the study. The data were analysed through frequency and percentage tables, means and standard deviations and simple linear regression as presented in the previous chapter.

\section{Personal information}

The study was carried out in the University of Cape Coast, in the Cape Coast Metropolis in the Central Region of Ghana, with a sample size of 76. The number of respondents from Agricultural Development Bank (4), Fidelity Bank (7), Ghana Commercial Bank (16), Prudential Bank Limited (6), Unibank Limited (17) and Zenith Bank (26) respectively.

Table 1: Gender distribution of respondents

\begin{tabular}{|l|c|c|}
\hline Gender & Frequency & Percentage (\%) \\
\hline Male & 34 & 44.7 \\
Female & 42 & 55.3 \\
\hline Total & $\mathbf{7 6}$ & $\mathbf{1 0 0 . 0}$ \\
\hline
\end{tabular}

From Table 1, the majority, 55.3percent of the respondents were females while 44.7percent of the respondents were males. The study, therefore, revealed that majority of the respondents were females. Table 2 represents age distribution of respondents in the study.

Table 2: Age of Respondents

\begin{tabular}{|l|c|c|}
\hline Age & Frequency & Percentage $\mathbf{( \% )}$ \\
\hline 15-24 years & 10 & 13.2 \\
25-34 years & 56 & 73.6 \\
35-44 years & 5 & 6.6 \\
45-54 years & 5 & 6.6 \\
\hline Total & $\mathbf{7 6}$ & $\mathbf{1 0 0 . 0}$ \\
\hline
\end{tabular}

From Table 2, the majority, 73.6 percent of the respondents were between the ages of 25 to 34 , 13.2percent of the respondents were between the ages of 15 to 24 and 6.6percent of the respondents were between the ages of 35 to 44 and 45 to54 respectively. It is therefore, observed from the study that majority of the respondents were between the ages of 25 to34.Table 3 represents the marital status distribution of respondents in the study.

Table 3: Marital Status of Respondents

\begin{tabular}{|l|l|l|}
\hline Status & Frequency & Percentage (\%) \\
\hline Single & 53 & 69.7 \\
\hline
\end{tabular}


Psychosocial Stress Among Bankers Due To Long Working Hours: Case Study Of University Of ..

\begin{tabular}{|l|l|l|}
\hline Married & 23 & 30.3 \\
\hline Total & $\mathbf{7 6}$ & $\mathbf{1 0 0 . 0}$ \\
\hline
\end{tabular}

From Table 3, the majority 69.7 percent of the respondents were single while 30.3 percent of the respondents were married. It is therefore, observed from the study that majority of the respondents were single. This implies that banks on University of Cape Coast campus have more single staff than married staff. Table 4 represents the educational level distribution of respondents in the study.

Table 4: Education Level of Respondents

\begin{tabular}{|l|c|c|}
\hline Level & Frequency & Percentage (\%) \\
\hline Post graduate & 4 & 5.3 \\
Graduate & 63 & 82.9 \\
Diploma & 9 & 11.8 \\
\hline Total & $\mathbf{7 6}$ & $\mathbf{1 0 0 . 0}$ \\
\hline
\end{tabular}

From Table 4, the majority 82.9 percent of the respondents were graduates, 11.8 percent of the respondents were diploma holders and 5.3 percent of the respondents were post-graduates. The study, therefore, revealed that majority of the respondents were graduates. It therefore, implies that the banks of the University of Cape Coast campus have graduates workers. Table 5represent work place distribution of respondents

Table 5: Workplace of Respondents

\begin{tabular}{|l|c|c|}
\hline Workplace & Frequency & Percentage (\%) \\
\hline ADB & 4 & 5.3 \\
FB & 7 & 9.2 \\
GCB & 16 & 20.0 \\
PBL & 6 & 7.9 \\
UL & 17 & 22.4 \\
ZB & 26 & 34.2 \\
\hline Total & $\mathbf{7 6}$ & $\mathbf{1 0 0 . 0}$ \\
\hline
\end{tabular}

From Table 6, the majority, 34.2 percent of the respondents worked at Zenith Bank (ZB), 22.4 percent of the respondents work at Unibank Limited (UL), 20.0 percent of the respondents worked at Ghana Commercial Bank (GCB), 9.2 percent of the respondents worked at Fidelity Bank (FB) while 7.9 percent and 5.3 percent of the respondents worked at Prudential Bank Limited (PBL) and Agricultural Development Bank (ADB), respectively. The study therefore revealed that majority of the respondents work at Zenith Bank. Table 6 represents the working hour's distribution of respondents in the study.

Table 6: Working Hours of Respondents

\begin{tabular}{|l|c|c|}
\hline Working Hours & Frequency & Percentage (\%) \\
\hline 30 and below & 3 & 3.9 \\
$31-40$ & 3 & 3.9 \\
$41-50$ & 25 & 32.9 \\
$51-60$ & 23 & 30.4 \\
61 and above & 22 & 28.9 \\
Total & $\mathbf{7 6}$ & $\mathbf{1 0 0 . 0}$ \\
\hline
\end{tabular}

In Table 7, the majority, 32.9 percent of the respondents were working between 41 and 50 hours, 30.4 percent of the respondents were working between 51 and 60 hours, 28.9 percent of the respondents each were working between 61 and above hours and 3.9 percent of the respondents each were working between 31 and 40 hours and 30 and below hours respectively. It was therefore, observed that majority of the respondents worked for 41 to 50 hours.

\section{Research Question one: What are the psychosocial stress among Bankers as a result of long working hours?}

Research question one sought to find out from respondents the psychosocial stress among bankers associated with long working hours. The question was assessed on a 5-point Likert scale (ranging from 1 to 5). For the interpretation of the means, the following cut-off points were used $(1-5=$ never, $1.5 \pm 2.5=$ seldom, $2.5 \pm 3.5=$ sometimes, $3.5 \pm 4.5=$ often and $4.5 \pm 5=$ always $)$.

Table 7: psychosocial Stress among Bankers due to long working hours

\begin{tabular}{|l|l|l|l|}
\hline Statement & N & Mean & Std. Deviation \\
\hline
\end{tabular}




\begin{tabular}{|l|l|l|c|}
\hline Different groups at work demand a lot & 76 & 3.01 & .973 \\
From me, things are hard to combine. & & & \\
I have unachievable deadlines. & 76 & 2.68 & .969 \\
I have to work very intensively. & 76 & 4.00 & 1.071 \\
I have to neglect some task because I have & & 2.93 & 1.247 \\
Too much to do. & 76 & 3.26 & 1.112 \\
I am unable to take sufficient breaks. & 76 & 3.59 & .99 \\
I am pressured to work long hours. & 76 & 3.71 & 1.017 \\
I have to work very fast. & 76 & 2.99 & 1.149 \\
I have unrealistic time pressures & & & \\
\hline
\end{tabular}

As revealed in Table 7, the statement showed that respondents have knowledge about psychosocial stress among bankers. Some respondents indicated that they would have to work very intensively, and they are pressured to work for long hours. Again, some also indicated that they would have to work very fast, different groups at work demand a lot from them, things that are hard to combine

The findings indicate that, respondents are aware of psychosocial stress associated with long working hours such as having unachievable deadlines, working very intensively, unable to take sufficient breaks, having unrealistic time pressures and have to neglect some task because they have too much to do. The findings are consistent with previous findings of (Osipow, 1998). In the literature, Osipow indicted that role overload measures the extent to which job demands exceed resources (personal and workplace) and the extent to which the individual is able to accomplish workloads. Marini et al. (1995) opined that role overload can result in an employee experiencing anger and frustration toward persons believed responsible for the overload in work. By implication, bankers experience a lot of psychosocial stress when there is too much work load and thereby hindering their productivity.

Research Question Two: What are the strategies that could be adopted by bankers to reduce stress associated long working hours among bankers in University of Cape Coast

Research question two sought to find out the strategies that could be adopted by bankers to reduce psychosocial stress associated with long working hours. The question was assessed on a 5-point Likert scale (ranging from 1 to 5). For the interpretation of the means, the following cut-off-points were used $(1-1.5=$ never, $1.5 \pm 2.5=$ seldom, $2.5 \pm 3.5=$ sometimes, $3.5 \pm 4.5=$ often and $4.5 \pm 5=$ always $)$.

Table 8: Strategies to reduce Psychosocial Stress

\begin{tabular}{|l|l|r|r|}
\hline Statement & N & Mean & Std. Deviation \\
\hline I can decide when to take a break. & 76 & 2.66 & 1.149 \\
I have a say in my own speed & 76 & 2.68 & 1.098 \\
I have a choice in deciding how I do my work. & 76 & 2.66 & 1.193 \\
I have some say over the way I work. & 76 & 2.34 & 1.126 \\
My working time can be flexible. & 76 & 2.28 & .918 \\
I am given supportive feedback on the work I do. & 76 & 3.72 & 1.103 \\
I can rely on my line manager to help me out with a work problem. & 76 & 4.13 & .854 \\
My line manager encourages me at work. & 76 & 3.34 & 1.250 \\
If work gets difficult, my colleagues will help me & 76 & 3.66 & 1.217 \\
My colleagues are willing to listen to my & & & \\
work-related problems. & 76 & 3.13 & 1.279 \\
\hline
\end{tabular}

As revealed in Table 8, the statement showed that majority of the respondents were aware of the strategies to reduce psychosocial stress among bankers. Respondents indicated that they often rely on their line managers to help them out with a work problem, when work gets difficult their colleagues would help them as they give them supportive feedback on their work they do. Moreover, respondents indicated that their colleagues are willing to listen to my work -related problems. However, some of the respondents indicated that they seldom have a choice in deciding how they do their work, they seldom have some say over the way they work and their working time are seldom flexible as well.

The findings of the study indicate that, some of the respondents are aware of the strategies that could be adopted to alleviate psychosocial stress as the banking sector. Respondents indicated that they could decide to take a break, get help from their colleagues when they are assigned a difficult task, get help from their colleagues when they are assigned a difficult task, seek an advice and encouragement from supervisors and also their colleagues were willing to listen to their work related problems so that the right antidote could be offered for it. The findings are supported by research work of (Healy \& Mckay, 2000). In the literature, Healy and Mckay asserted that in coping with stress, individuals sometimes let others know their opinions and also resort to seek assistance from their colleagues. By implication, individuals who are able to cope with stressful situations are able to live up to task. 


\section{Hypothesis}

Ho: There is no statistical significant relationship between psychosocial stress and health of bankers. H1: There is statistical significant relationship between psychosocial stress and health of bankers.

Research hypothesis sought to find out the significant relationship between psychosocial stress and health of bankers.

Table 9: Relationship between psychosocial Stress and Health of bankers

\begin{tabular}{|c|l|l|l|l|l|l|}
\hline Model & \multicolumn{2}{l|}{$\begin{array}{l}\text { Unstandardized } \\
\text { Coefficients }\end{array}$} & \multicolumn{1}{l|}{$\begin{array}{l}\text { Standardized } \\
\text { coefficients }\end{array}$} & t & Sig. \\
\hline & $\mathrm{B}$ & Std. Error & Beta & & & \\
\hline 1 (constant) & 9.807 & 1.015 & & & 9.659 & .000 \\
Stress & -.010 & .038 & & -.030 & -.256 & .799 \\
\hline
\end{tabular}

a. Dependent Variable: health

From Table 9, the result shows that psychosocial stress does not affect the health of bankers $(r=.030$, $\mathrm{p}>$.05). Psychosocial stress accounts for .1 percent of the variation in the health of bankers. The result of the test shows that psychosocial stress does not affect the health of bankers $(r=.030, \mathrm{p}>.05)$. psychosocial stress accounts for $.1 \%$ of the variation in the health of bankers. This implies that psychosocial stress in the banking sector do not have a toll on the health of bankers in the University of Cape Coast in the Central Region of Ghana.

\section{Overview of the Study}

\section{Summary}

This study was a cross - sectional design survey that examined the impact that of psychosocial stress among bankers in University of Cape Coast in the Central Region of Ghana. The study focused specifically on the following: examine the psychosocial stress on bankers due to long working hours, find out the strategies that bankers could adopt to reduce stress associated with long working hours and lastly assess the impact of stress on the health of bankers.

The study was conducted in the University of Cape Coast, in the Cape Coast Metropolis of Ghana. Convenient sampling method was used to select bankers in the University of Cape Coast. The sample size for the study comprised 76 bankers working in the banks on the University of Cape Coast campus.

A 30-item questionnaire was the main instrument for data collection. The data collected were analysed mainly by frequency, percentage tables, means and standard deviations and simple linear regression.

\section{Key Findings}

The following are the main findings from the data analysis.

Under the psychosocial stress associated with long working hours among bankers in the University of Cape Coast, bankers indicated that they often have unrealistic time pressure. Again, they indicated that they are often pressured to work for long hours, and are unable to take breaks. Also, bankers indicated that they have unachievable deadlines and that different groups at work demand things from them which was therefore, hard to combine.

Under the strategies bankers would adopt to reduce psychosocial stress, bankers indicated that when work gets difficult, they seek assistance from their colleagues. Again, they indicated that their line managers help them out with their problems. Moreover, bankers indicated that their colleagues are willing to listen to their work related problems.

Under the hypothesis, there is no statistical relationship between psychosocial stress and health of bankers. The result of the test showed that there is no significant relationship between psychosocial stress and health of bankers. Therefore psychosocial stress does not affect health of bankers $(r=.030, p>.05)$.

\section{Conclusions}

The results of the study indicated that on the psychosocial stress associated with long working hours among bankers, bankers generally reported that they were aware of the psychosocial stress based on the statement outlined on the questionnaires. It could therefore, be concluded that, to a great extent, bankers in the University of Cape Coast were aware of psychosocial stress associated with long working hours.

On the strategies to reduce psychosocial stress, bankers generally reported that they were aware of the strategies based on the statement outlined on the questionnaire. It could therefore, be concluded that, to a great 
extent bankers in the University of Cape Coast were aware of strategies to reduce psychosocial stress associated with long working hours.

On the hypothesis, there is no statistical significant relationship between psychosocial stress and health of bankers. The result of the test showed that there is no significant relationship between psychosocial stress and health of bankers. It could therefore, be concluded, to a great extent that psychosocial stress associated with long working hours do not affect the health of bankers.

\section{Recommendations for Policy and Practice}

\section{Recommendations}

In view of the above research findings and the conclusions arrived at, the following recommendations were made:

1. Under the strategies adopted by bankers to reduce psychosocial stress associated with long working hours, the findings indicated that bankers still have a gap in knowledge. It is recommended that management of the banks in the University of Cape Coast collaborate with the University counselors to organize seminars, workshops, forum etc. for the staff. This would aid staff of the banks in the University of the University of Cape Coast to be aware to strategies that could be adopted to alleviate psychosocial stress.

2. The banks should also arrange that their staff could once a while have a brief time as break to relax their nerves a bit.

\section{Reference}

[1]. Berkowitz, B., \& Clark, P. (2014). The health hazards of sitting (Electronic Version). The Washington Post. Retrieved February 2016, from http://app.washingtonpost.com/g/page/national/the-health-hazards-of sitting/750/

[2]. Best, J. W., \& Kahn ,J. V. (2002). Research in Education ( $\left(^{\text {th }}\right.$ ed). Boston: Allyn And Bacon.

[3]. Biggs, H., Flett, R., Voges, K., \& Alpass, F. (1995). Job satisfaction and distress

[4]. In rehabilitation professionals: the role of organization commitment and conflict. Journal of Applied Rehabilitation Counseling, 20(1), I41- 46.

[5]. Bixby, S. (2014). What working long hours actually does to your body (Electronic version). News Mic. Retrieved February 2016, from http://m.mic.comlarticles 104550 lwhat-working-long-hours-actually does-to-your-body\#, CKDWUuaP6

[6]. Blumenthal, J. A., Emery, C. F., \& Madden, D. J. (2005) Cardiovascular and behavioral effects of aerobic exercise training in healthy older men and Women. Journal of Gerontology, 44, 147-157.

[7]. Borg, W. R., \& Gall, M.D. (1989). Educational research. (5 ${ }^{\text {th }}$ ex.). New York and London: Longman, Inc.

[8]. Börjesson, M., \& Dahöf, B. (2005). Physical activity has a key role in Hypertension therapy. Lakartidninden, 102(3), 123-129.

[9]. Bunde, J., \& Suls, J. (2006). A quantitative analysis of the relationship between The Cook-Medley Hostility Scale and traditional coronary artery disease Risk factors. Health Psychology, 25, 493-500.

[10]. Chesney, M. A., \& Rosenman, R. H. (1983). In C.L. Cooper, Stress research: Issues for the eighties (pp. 21-34). New York: John Wiley \& Sons.

[11]. Chobanian, V. A., (2001). Control of hypertension: an important National priority. The New England Journal of Medicine. 345, 534-535.

[12]. Clay, E., (2001). Job strain as a risk factor for coronary heart disease: a Collaborative meta-analysis of individual participant data. Lancet, 380(9852), 1491-1497.

[13]. Cooper, D. R., \& Schindler, P. S. (2003). Business Research Methods $\left(8^{\text {th }}\right.$ ed.). USA: McGraw-Hill.

[14]. Cox, T. (1979). Stress. Baltimore. University Park Press.

[15]. Decker, P. J., \& Borgen, F. H. (1993). Dimensions of work appraisal: stress, Strain, coping, job satisfaction, and negative affectively. Journal of Counselling Psychology, 40(4), 470-478.

[16]. Derogatis, L. R., \& Coons H.L. (1993). Self-report measures of stress. In L.

[17]. Golberger \& S. Breznitz(Eds.), Handbook of stress: Theoretical and clinical aspects (2 ${ }^{\text {nd }}$ ed.) (pp.200-233). New York: the Free Press.

[18]. Folkman, S., \& Lazarus, R.S. (1988). Coping as a mediator of emotion. Journal of Personality and Social Psychology, 54(3), 466475 .

[19]. Fogarty, G.J., Machin, A., Albion, M. J., Sutherland , L.F., Lalor, G.I., \& Revitt, S. (1999). Predicting occupational strain and job satisfaction: the role of stress, coping personality , and affectivity variables. Journal of Vocational behavior, 54(3), 429-452.

[20]. Fraenkel, J.R. \& Wallen N.E. (2001). Educational research: a guide to the Process (2 ${ }^{\text {nd }}$ ed.). Mahwah, NJ: Lawrence Erlbaum Associates publishers.

[21]. Frasure -Smith, N., \& Lesperance. F. (2005). Reflection on depression as a cardiac risk factor. Psychosomatic Medicine, 67(1), 1925.

[22]. French, R.P., Caplan , R.D., \& Harrison , R.V. (1982). The Mechanism of Job Stress And Strain. New York: John wiley \& Sons

[23]. Geipert, N.(2007). Don't be mad. American Psychology Association, 38(1), 50 Ghadially, R., \& Kumar, P. (1987). Stress, strain and coping styles of female Professionals. Indian Journal of Applied Psychology, 26(1), 1-8.

[24]. Greenberg, J.S.(1999). Comprehensive Stress Management (6 ${ }^{\text {th }}$ ed.) New York: WCB/McGraw-Hill.

[25]. Healy, C. M., \& Mckay, M.F. (2000) Nursing Stress: the effect of Coping Strategies and job satisfaction in a sample of Australian nurses. Journal of Advanced nursing, 31(3), 681-699.

[26]. Hlu, F.B., \& Willet, W.C.(2001). Optimal diets for prevention of coronary heart disease. The journal of the American Medical Association, 288(20), 2569-2578.

[27]. Hyman , D.J., \& Willet, W.C. (2002). Characteristics of patients with Uncontrolled hypertension in the United States. The New England Journal of Medicine, 345(7),479-486 
Psychosocial Stress Among Bankers Due To Long Working Hours: Case Study Of University Of ..

[28]. Januzzi, L.J.J., \& Stern, T.A., Pasternak , R.C.,\& DeSanctis, R.W.(2000). The Influence of anxiety and depression on outcomes of patients with Coronary artery disease. Journal of the America Medical Association,160, 13

[29]. Kahn, R.L.(1986). On the conceptualization of stress. In A. Eichler, M.M. Silverman, \& D.M. Pratt (Eds.), How to define and research stress (pp.41-43). Washington, DC: American Psychiatric Press, Inc.

[30]. Kiecolt -Glaser, J.K., McGuire, L., Robles, T.F., \& Glaser, R. (2002). Psychoneuroimmunology: psychological influences on immune function and health. Journal of Consulting and Clinical Psychology, 70(3), 537-547.

[31]. Krejcie, R.V., \& Morgan, D.W.(1970). Determining sample size for research activities. Educational and Psychological Measurement, 30(3). 607-610

[32]. Lazarus, R. S., \& Folkman, S. (1986). Stress as a rubic . In A. Eichler, M.M. Silverman \& D. M. Pratt (Eds.), how to define and research stress (pp.49-53). Washington, DC: American Psychiatric Press, Inc.

[33]. Marini, I., Todd, J., \& slate, J.R. (1995). Occupational stress among mental health employees. Journal of Rehabilitation Administration, 19(2), 123-130.

[34]. Meichenbaum, D. (1986). Towards a conceptualization of stress. In A. Eichler, M.M. Silverman, \& D.M. Pratt (Eds.) How to define and research stress (pp.55-57). Washington, DC: American Psychiatric Press, Inc.

[35]. Mendelsohn, M.E., \& Karas, R.H. (2005). Molecular and cellular basis of Cardiovascular gender differences. Science, 308(5728), 1587.

[36]. Nabel , G.E. (2003) . cardiovascular disease. The New England Journal of Medicine, 349,60-72.

[37]. Orodho, M.(2003) Essential of education and social sciences research methods. Nairobi: Mosala Publishers.

[38]. Orth-Gomer, K., Wamala, S.P., Horsten, M., Schenk-Gustafsson, K., Schneiderman , N., \& Mittleman , M.A.(2000). Marital stress worsens Prognosis in women with coronary heart disease. The Journal of the American Medical Association 284, 30083014.

[39]. Osipow, S.H. (1998). Occupational Stress Inventory Manual (professional version ). Odessa, FL: Psychological Assessment Resources.

[40]. Osipow, S.H., \& Spokane, A. R. (1987) Occupational Stress Inventory Manual (research vision). Odessa, FL: Psychological Assessment Resources.

[41]. Pithers, R. T., \& Soden, R. (1999). Person-environment fit and teacher stress Educational Research, 4(1), 51-61.

[42]. Pressman, S.D.,\& Cohen, S. (2005). Does positive affect influence health? Psychological Bulletin, 131,925-971.

[43]. Richard, G.V., \& Krieshok, T.S.(1989). Occupational stress, strain and coping In University faculty. Journal of Vocational Behaviour, 34(1), 117 - 132

[44]. Rutledge, T., \& Hogan, B.E.(2002). A quantitative review of prospective evidence linking psychological factors with hypertension development. Psychosomatic Medicine, 64(5), 758-766.

[45]. Ryan, R.R.(1996). A survey of occupational stress psychological stain and Coping resources in licensed professional counsellors in Vurginia. Unpublished doctoral dissertation, Virginia Polytechnic Institute and State University .

[46]. Sarafino, E.P. (2012). Health psychology: Biopsychosocial Intereactions $\left(7^{\text {th }}\right.$ ed). Asia : Wiley.

[47]. Scott, E. (2014). What is psychosocial stress (Electronic version )? Verywell.

[48]. Retrieved February 2016, from http://www.verywell.com/what-ispsychosocial-stress-3145133

[49]. Selye, H. (1974). Stress without distress. New York: J.B. Lippincott Company.

[50]. Selye,H.(1976). The stress of life (revised ed.). New York: McGraw Hill.

[51]. Selye, H. (1983). The stress concept: past present, and future. In C.L. Cooper (Ed.), Stress research: Issues for the eighties (pp.120). New York, NY: John Wiley \& Sons.

[52]. Selye, H. (1993). History of stress concept. In L. Goldberger \& S. Breznitz (Eds.), Handbook of stress: Theoretical and clinical aspects $\left(2^{\text {nd }}\right.$ ed.) (pp.7-17). New York: The Free Press.

[53]. Steptoe, A., Wardle, J., \& Marmot, M. (2005). Positive affect and health - Related neuroendocrine , cardiovascular, and inflammatory processes. Proceeding of the National Academy of Science, 102(18), 6508-6512.

[54]. Stoner, J.A.F., \& Freeman, R.E. (1992). Management ( $5^{\text {th }}$ ed.). New Jersey : Prentice Hall

[55]. Suinn, R. (2001) (Ed.), Psychology in sports: Methods and applications. (pp. 275-287). Minneapolis, MN: Burgess

[56]. Sutherland, L.F., Fogarty, G.J., \& Pithers, R.T.(1995). Congruence as a Predictor of occupational stress, Journal of Vocational Behaviour, 46(3), 292-309.

[57]. Trivette , P.S. (1993). A national survey of occupational stress, psychological Strain and coping resources in elementary school counsellors. Unpublished doctoral dissertation, Virginia Polytechnic Institute and State University.

[58]. Virtanen , M., Singh-Manoux , A., Ferrie, J.E., Gimeno, D., Marmot , m.G., Elovainio, M., Jokela, M., Vahtera, J., \& Kivimaki, M. (2009). Long Working hours and cognitive function. American Journal of Epidemiology, 169(5), 596.

[59]. Yin, R. (1994). Case study research : Design and methods ( $2^{\text {nd }}$ ed.). Thousand Oaks, CA: Sage Publishing . 